\title{
Neonatal Leukemoid Reaction: Correspondence
}

\author{
Mandal A' ${ }^{1}$ Sahi PK ${ }^{2}$
}

To the Editor,

We read with much interest the article by Bhatia et al., published in the recent issue of your journal ${ }^{1}$ but at the same time would like to make the following comments, clarification to which would benefit the general readers of JNPS.

First: The neonate presented in the case was a preterm (34 weeks of gestation) with history of premature rupture of membranes in the mother; both risk factors for early onset sepsis in the newborn. The authors also mention that "The complete blood count was repeated on alternate days and showed a decreasing trend"; there were also no blasts in the peripheral smear and a positive blood culture growing Group B streptococci (GBS). All of the above combined with a clinical improvement in the baby with intravenous antibiotics, was reassuring that the leukemoid reaction was due to sepsis ${ }^{2}$. On the other hand, in the absence of organomegaly and thrombocytopenia, congenital/ infantile leukemia also becomes unlikely. In this scenario, the utility of performing a bone marrow examination (that too biopsy!) in the newborn is really questionable.

Second: It is expected to find plenty of nucleated red blood cells (nRBCs) in the peripheral blood of the patient as both prematurity and early onset sepsis are known to increase their numbers. Automated hematology analyzers may falsely count these nRBCs as leucocytes, giving spuriously high leucocyte count ${ }^{3}$. Most new generation analyzers give flags (WBC* R, NRBC, Review Slide, Blasts etc.) to identify abnormal cells and in such cases the samples should be reviewed manually ${ }^{4}$. Though the authors have not given the $\mathrm{nRBC}$ count, in such scenarios, it is advised to calculate the corrected WBC count using the following formula: corrected WBC count $(/ \mathrm{mm} 3)=$ TLC X $100 \div\{\text { nRBC per } 100 \mathrm{WBC}+100\}^{5}$.

Third: The authors mention that "The karyotype was also normal hence the possibility of transient myeloproliferative disorder (TMD) seen with patients with Down's syndrome was also ruled out". The diagnosis of TMD is made in a newborn with Down syndrome with leukocytosis, blasts in peripheral blood with or without thrombocytopenia ${ }^{6}$. But the index newborn neither seem to have Down's phenotype nor blasts in peripheral blood, hence the utility of getting a karyopying done is also not clear.

Fourth: It is mentioned that "the possibility of Leucocyte adhesion defect (LAD)" was also considered but as "the umbilical cord fell on the fourth day which ruled out the possibility of LAD". It should be mentioned that delayed fall of umbilical cord is not observed in
${ }^{1}$ Dr. Anirban Mandal, Department of Pediatrics, Sitaram Bhartia Institute of Science and Research, New Delhi, India, ${ }^{2}$ Dr. Puneet Kaur Sahi, Department of Pediatrics, Kalawati Saran Children's Hospital, New Delhi, India.

\section{Address for correspondence \\ Dr. Puneet Kaur Sahi \\ E-mail: puneetksahi@gmail.com}

\section{How to cite}

Mandal A, Sahi PK. Neonatal Leukemoid Reaction: Correspondence. J Nepal Paediatr Soc 2017;37(1):108-109.

doi:http://dx.doi.org/10.3126/jnps.v37i1.17166

This work is licensed under a Creative Commons Attribution 3.0 License. 
patients with LAD type $1 \mathrm{I}^{7}$. Thus, in a case of 'suspected LAD', the diagnosis should not be excluded on the basis of absence of delayed fall of umbilical cord only.

Response from Author: Nil

\section{References}

1. Bhatia R, Bhatia G. Neonatal Leukemoid Reaction - A diagnostic dilemma. J Nepal PaediatrSoc 2016;36(3):298-299. DOI: http://dx.doi.org/10.3126/ jnps.v36i3.15611

2. GeorgeTI.Malignantorbenignleukocytosis. Hematology Am SocHematolEduc Program.2012;2012:475-84. DOI: doi: 10.1182/asheducation-2012.1.475

3. Dulay AT, Buhimschi IA, Zhao G, Luo G, Abdel-Razeq $S$, Cackovic M, et al. Nucleated red blood cells are a direct response to mediators of inflammation in newborns with early-onset neonatal sepsis. $A m J$ ObstetGynecol 2008;198(4):426.e1-9. DOI: http:// dx.doi.org/10.1016/j.ajog.2008.01.040

4. Barnes PW, McFadden SL, Machin SJ, Simson $\mathrm{E}$; international consensus group for hematology.
Response from Editor: We tried to contact the author of the said article but have not got any reply as yet. We shall pursue your feedback and try to make things clear. Thank you for pointing out such issues because this is how medical publishing from this side of the world would progress.
The international consensus group for hematology review: suggested criteria for action following automated $\mathrm{CBC}$ and WBC differential analysis. LabHematol2005;11(2):83-90.

5. Mandal A, Sahi PK. Leukemoid Reaction Due to P. falciparum Infection: Correspondence. Indian J Pediatr. 2017;84(3):251.DOI: 10.1007/s12098-016-2237-5

6. Singh A, Mandal A, Guru V, Srinivasand S, Seth R. Transient Abnormal Myelopoiesis: A Varied Spectrum of Clinical Presentation. J Hematol. 2017;6(1):25-28. DOI: https://doi.org/10.14740/jh306w

7. Yakubenia S, Wild MK. Leukocyte adhesion deficiency II. Advances and open questions. FEBS J. 2006;273(19):4390-8. DOI: https://doi.org/10.14740/ jh306w 